\title{
Wybrane aspekty opieki pielęgniarskiej realizowanej wobec pacjenta po przebytym udarze niedokrwiennym mózgu
}

\section{Selected aspects of nursing care provided to patient after ischemic stroke}

\section{KASANDRA SZKLARCZYK ${ }^{1}$, WIKTORIA SZTANDAROWICZ ${ }^{1}$, EMILIA SZYJKOWSKA ${ }^{1}$, PAULINA SAK ${ }^{1}$}

\footnotetext{
1Studenckie Koło Naukowe Nauk o Zdrowiu¹, Instytut Nauk o Zdrowiu, Państwowej Uczelni Zawodowej we Włocławku opiekun koła: dr Beata Haor
}

DOI: http://dx.doi.org/10.21784/IwP.2020.023

ISSN: $2451-1846$

\section{Streszczenie}

Wstęp. Udar mózgu to zespół kliniczny, w którym dochodzi do nagłych zmian ogniskowych bądź globalnych zaburzeń czynności mózgowia. Mimo zauważalnego $\mathrm{w}$ ciągu ostatnich lat postępu $\mathrm{w}$ diagnostyce oraz możliwościach leczenia, udar mózgu stanowi trzecią co do częstości przyczynę zgonów w krajach uprzemysłowionych. W Polsce rocznie odnotowuje się 60 tysięcy przypadków udaru, z czego połowa w ciągu pierwszego roku umiera. Pacjenci po udarach często stają się niesamodzielni oraz zależni od innych osób.

Cel. Celem pracy jest analiza wybranych aspektów opieki pielęgniarskiej realizowanej wobec pacjenta po przebytym udarze niedokrwiennym mózgu.

Materiały i metody. W pracy użyto metody analizy piśmiennictwa związanego z zagadnieniem udaru mózgu oraz opieki nad pacjentem po przebytym udarze, jak również mapowanie diagnoz i interwencji pielęgniarskich z zastosowaniem słownika ICNP $₫$

Wyniki i wnioski. Użycie klasyfikacji ICNP® pozwala ukazać stan zdrowia 
pacjenta po przebytym udarze mózgu oraz zaplanować opiekę pielęgniarską opierając się o jednolitą terminologię zawodową.

Słowa kluczowe: opieka pielęgniarska; udar mózgu; pacjent; ICNP®.

\begin{abstract}
Introduction. Stroke is a clinical syndrome in which focal or global brain dysfunction suddenly occurs. Despite the progress in diagnostics and treatment options that has been noticeable in recent years, stroke is the third most common cause of death in industrialized countries. In Poland, there are 60,000 people after a stroke every year, half of them die during the first year. Stroke patients often become dependent and needs help from other people.

Aim. The aim of this study is to analyze selected aspects of nursing care provided to a patient after an ischemic stroke.

Material and methods. Analysis of available literature related to issue of stroke and nursing care in patients after stroke as well as mapping medical diagnosis and interventions using the INCP $®$ dictionary.

Results. Using the ICNP classification allows to show the patient's state of health after a stroke and plan nursing care based on uniform professional terminology.
\end{abstract}

Keywords: nursing care; stroke; patient; ICNP®.

\title{
Wstęp
}

Według Światowej Organizacji Zdrowia udar mózgu należy definiować jako „zespół kliniczny charakteryzujący się nagłym pojawieniem się ogniskowych lub globalnych zaburzeń czynności mózgowia, które - jeżeli nie doprowadzą wcześniej do zgonu utrzymują się dłużej niż 24 godziny i nie mają innej przyczyny niż naczyniowa".

Podobnie definiuje chorobę Amerykański Narodowy Instytut Chorób Układu Nerwowego i Udaru Mózgu z 1990 r. - „zespół objawów wynikłych z czasowego lub stałego upośledzenia funkcji ośrodkowego 
układu nerwowego przez proces niedokrwienny lub krwotoczny, w którym doszło do pierwotnego uszkodzenia jednego lub wielu naczyń mózgu przez proces patologiczny". [1] Udar mózgu powstaje poprzez zamknięcie tętnicy przez materiał zatorowy bądź miejscowo rosnący zakrzep. Występuje on nagle $\mathrm{w}$ przebiegu upośledzenia krążenia mózgowego wskutek niedokrwienia lub krwotoku[2,3]. W wyniku udaru następuje szybko postępujące pogorszenie sprawności intelektualnej i fizycznej chorego. Przyczyną udaru jest zawał mózgu bądź krwotok do mózgu. Zawał jest skutkiem zakrzepu bądź zatoru, jak i również zaburzeń czynnościowych serca. Krwotok pojawia się w miejscu uszkodzenia ściany naczynia, zazwyczaj przez miażdżycę lub tętniak [4]. Udar stanowi nadal główną przyczynę zgonów w populacji osób dorosłych, jak i również istotną przyczynę niepełnosprawności oraz zależności społecznej. Jak podają dane WHO - udar mózgu odpowiedzialny jest za 10\% wszystkich zgonów. W Polsce wykazano, iż rocznie odnotowuje się udar mózgu u 60 tysięcy osób, z czego połowa umiera w ciągu roku oraz ma trwałe deficyty przyczyniające się do niesamodzielności człowieka [5]. Udar mózgu jest stanem bezpośredniego zagrożenia życia i musi być traktowany przez wszystkich pracowników ochrony zdrowia jako stan wymagający niezwłocznej pomocy oraz szybkiej reakcji według procedur.

Rozpoznanie choroby w krótkim czasie pozwala na wdrożenie adekwatnej terapii, co może przyczynić się do uratowania życia choremu oraz dania możliwości uniknięcia poważnego kalectwa, które niesie za sobą udar.[2]

W zależności od mechanizmu chorobotwórczego niedokrwienne zaburzenia krążenia w ośrodkowym układzie nerwowym dzieli się na:

- zakrzepowo-zatorowe,

- zatorowe,

- zatokowe,

- hemodynamiczne. 
W mechanizmie zakrzepowo - zatorowym przejawia się zawał mózgu, który stanowi 14-40\% wszystkich udarów. Spowodowany jest miażdżycą tętnic, która rozwija się głównie w miejscu ich podziału.

Proces ten przejawia ścisły związek z przewlekłym nadciśnieniem tętniczym u chorych. Następuje stopniowe zwężanie się tętnic mózgowych, a w zaawansowanym stadium dochodzi do całkowitego zamknięcia światła naczynia. Początkowo w naczyniach dochodzi do przerostu błony wewnętrznej, po czym uszkodzeniu ulegają głębsze warstwy ściany naczynia. W większości udarów zakrzepowo zatorowych pojawiają się objawy zwiastunowe, które wynikają z przemijających upośledzeń czynności mózgu, związanych z niedokrwieniem obszaru unaczynienia tętnic szyjnych wewnętrznych bądź kręgowych. W zespołach TIA tętnic szyjnych wewnętrznych można zaobserwować objawy takie jak:

- niedowład połowiczy,

- opadnięcie kącika ust,

- zaburzenia mowy,

- zaburzenia czucia w obrębie twarzy, kończyny górnej lub dolnej;

- zaburzenia widzenia.

Udary zatorowe stanowią 15-30\% wszystkich udarów. Pod pojęciem udar zatorowy rozumie się niedokrwienie, które powstało w sytuacji, gdy źródło zatoru znajduje się poza naczyniami mózgowymi bądź bezpośrednio doprowadzającymi krew do mózgu. Najczęstszym materiałem zatorowym jest skrzeplina niesiona $\mathrm{z}$ prądem krwi do naczyń mózgowych. Materiał zatorowy ma zazwyczaj pochodzenie sercowe. W skutek chorób serca, takich jak migotanie przedsionków, inne zaburzenia rytmu serca, przebyty zawał mięśnia sercowego, powstają przyściennie skrzepliny komory bądź przedsionka, które po rozłączeniu się stanowią materiał zatorowy. Objawy udaru zatorowego występują bez uprzedzenia oraz nie zwiastują ich żadne objawy, w przeciwieństwie do udaru zakrzepowo-zatorowego. Ze względu na 
miejsce, które najczęściej obejmuje zator - tętnicę środkową mózgu dochodzi do pojawienia się połowiczego niedowładu/porażenia kończyny górnej, niedowładu centralnego nerwu twarzowego, a w przypadku lewej strony można zaobserwować upośledzenie mowy.

Udary lakunarne, inaczej zatokowe, występują $\mathrm{z}$ częstością podobną do udarów zatorowych (15-30\%). Najczęściej są one skutkiem upośledzenia małych naczyń. Dotyczą one struktur podkorowych - torebka wewnętrzna, jądra podstawy, wzgórze, pień mózgu. Udary są spowodowane zamknięciem, zatkaniem niewielkich naczyń przeszywających.

Udary hemodynamiczne dotyczą zaburzeń systemowych perfuzji w otoczeniu ośrodkowego układu nerwowego, wynikających z nagłego, niewystarczającego krążenia $\mathrm{np}$. w wyniku wstrząsu hipowolemicznego bądź nagłego zatrzymania krążenia. Udar hemodynamiczny spowodowany jest niedostatecznym dopływem krwi do mózgu z uwagi na nagły spadek ciśnienia tętniczego. Zmiany niedokrwienne dotyczą zazwyczaj obrębu unaczynienia dwóch, bądź więcej, tętnic mózgowych. Obszary te nazywane są „ostatnią łąką”.

Najczęściej udar niedokrwienny dotyka płatu ciemieniowego oraz czołowego, na granicy unaczynienia tętnicy środkowego oraz przedniej mózgu $[1,2]$.

W zależności od dynamiki objawów udary dzieli się na:

- przemijający napad niedokrwienny mózgu (transient ischaemic attack - TIA), rozumiany jest jako wystąpienie ogniskowego ubytku czynności części mózgowia, w tym siatkówki, spowodowany niedokrwieniem. Trwa nie dłużej niż 24 godziny. Większość epizodów trwa od kilku do kilkunastu minut, nieczęsto przekraczając godzinę.

- odwracalny niedokrwienny ubytek neurologiczny (reversuble ischaemic neurologic deficyt- RIND)- objawy ustępują w przeciągu 21 dni. 
- zawał mózgu - stwierdza się, gdy zostanie stwierdzone ustabilizowanie kliniczne objawów klinicznych udaru.

- udar postępujący - występuje, gdy stwierdzi się wzmożenie objawów ogniskowych w pierwszej dobie, głównie w przeciągu 6 godzin po udarze; stabilizacja następuje najczęściej w 3 dobie $[1,2]$.

W przypadku udarów niedokrwiennych $(80-85 \%$ wszystkich udarów) objawy neurologiczne pojawiają się $\mathrm{w}$ wyniku niedostatecznego zaopatrzenia w krew tkanki mózgowej. Najczęstszymi przyczynami są zwężenia miażdżycowe tętnicy bądź zatory [3].

Objawy sugerujące udar mózgu:

- zaburzenia tzw. wyższych czynności nerwowych - nagłe problemy w mówieniu i/lub rozumieniu mowy (afazja) oraz artykulacji (dyzartria);

- nagłe zaburzenia widzenia na jedno oko, podwójne widzenia;

- nagłe trudności w chodzeniu;

- ostry ból głowy;

- zawroty głowy bądź nagła utrata świadomości- zaburzenia przytomności przyjmują różną postać, od senności do głębokiej śpiączki;

- nagłe pogorszenie funkcji poznawczych;

- zaburzenia tzw. wyższych czynności nerwowych;

- zaburzenia czucia;

- porażenie bądź niedowład połowiczy. [2,3]

Znajomość czynników ryzyka jest niezmiernie potrzebna w praktyce pielęgniarskiej, gdyż pozwala na identyfikację poszczególnych osób bądź większych populacji o zwiększonym ryzyku wystąpienia udaru. Wśród czynników ryzyka niedokrwiennych zaburzeń krążenia wyróżnia się czynniki modyfikowalne oraz niemodyfikowalne: 
1. niemodyfikowalne, znamienne czynniki ryzyka udaru:

- wiek- powyżej 55 r.ż.,

- płeć- ryzyko wyższe wśród mężczyzn (mężczyźni/kobiety: $1,3 / 1,0)$

- rasa oraz czynniki genetyczne - częściej występuje wśród rasy czarnej

2. modyfikowalne czynniki ryzyka udaru mózgu, zależne od stylu życia i wpływów środowiskowych:

- stosowanie używek i biologicznie aktywnych środków chemicznych; nikotynizm 2,5-3-krotnie zwiększa ryzyko udaru;

- niewłaściwy sposób odżywiania i otyłość, która 1,5-krotnie zwiększa ryzyko udaru;

- zbyt niska aktywność fizyczna;

- złe warunki socjoekonomiczne oraz niski poziom edukacji.

3. modyfikowalne czynniki zależne od występowania chorób oraz zaburzeń metabolicznych:

- nadciśnienie tętnicze- stwarza 3 - 6 - krotnie większe ryzyko;

- cukrzyca powoduje 1,8 - 2,2 - krotny wzrost ryzyka;

- choroby mięśnia sercowego, układu bodźcoprzewodzącego i zastawek serca;

- dyslipidemie;

- choroby krwi;

- zespół zaburzeń metabolicznych związanych z niewydolnością nerek;

- niedoczynność tarczycy;

- niemiażdżycowe choroby tętnic szyjnych i mózgowych.

4. czynniki biochemiczne i hematologiczne stwierdzane w badaniach laboratoryjnych:

- zwiększone stężenie białka C-reaktywengo w surowicy oraz fibrynogenu w osoczu, 
- podwyższone wartości hematokrytu,

- hiperhomocysteinemia i homocysteinuria. [1]

Pacjenci po udarach często pozostają niesprawni oraz uzależnieni od opiekunów. Ograniczenia mogą dotyczyć czynności samoobsługowych związanych $\mathrm{z}$ zaburzeniami mobilności oraz przykurczami w obrębie kończyny górnej, jak i również nietrzymaniem moczu i stolca. Trudności mogą pojawić się również zmianie pozycji w łóżku, poruszaniu się oraz spożywaniu pokarmu. Może dojść do zaburzeń komunikowania się z otoczeniem, co przyczynia się do izolacji społecznej, nasilającej istniejącą depresję. [4]

\section{Cel}

Celem pracy jest analiza wybranych aspektów opieki pielęgniarskiej realizowanej wobec pacjenta po przebytym udarze niedokrwiennym mózgu.

\section{Materiały i metody}

W pracy użyto metody analizy piśmiennictwa związanego z zagadnieniem udaru mózgu oraz opieki nad pacjentem po przebytym udarze, jak również mapowanie diagnoz i interwencji pielęgniarskich z zastosowaniem słownika ICNP $®$ (wersja z 2019r.) [6]

\section{Prezentacja przypadku}

Poniżej przedstawiono propozycje opieki pielęgniarskiej nad pacjentem po przebytym udarze niedokrwiennym mózgu, hospitalizowanego w oddziale neurologii.

Diagnoza pielęgniarska nr 1. Ryzyko zaburzenia funkcji układu nerwowego [10037333].

Przedmiot: Potencjalne ryzyko [10017252].

Potencjalne ryzyko: zjawisko: ryzyko utraty lub wystąpienia problemu, 
spodziewane wystąpienie problemu o pewnym prawdopodobieństwie; potencjalny stan negatywny.

Interwencje:

1. Monitorowanie statusu neurologicznego [10035326];

2. Monitorowanie statusu fizjologicznego [10012183];

3. Planowanie opieki [10035915];

4. Zapewnienie ciągłości opieki [10006966];

5. Administrowanie lekiem [10025444];

6. Ewaluacja reżimu leczenia [10031268];

7. Zapewnienie rodzinie wytycznych dotyczących przyszłości [10026375];

8. Uzgadnianie przestrzegania zaleceń [10024349];

9. Nauczanie rodziny o chorobie [10021719];

10. Nauczanie rodziny o reżimie terapii [10024656]. Diagnoza/wynik: Efektywny status neurologiczny [10033811].

Diagnoza pielęgniarska nr 2. Porażenie [10014006].

Przedmiot: Zaburzony proces układu mięśniowo - szkieletowego [10012773].

Porażenie: zaburzony proces układu mięśniowo - szkieletowego: nieprawidłowa kondycja charakteryzująca się utratą funkcji mięśni i/lub utratą doznań, utratą zdolności poruszania ciała lub jego części wraz z utratą kontroli nad czynnościami jelit i pęcherza moczowego, dystres oddechowy związany $\mathrm{z}$ urazem, zmiany $\mathrm{w}$ mechanizmie nerwowym lub mięśniowym, bądź w wyniku traumy takiej jak uraz rdzenia kręgowego, choroby lub zatrucia.

Interwencje:

1. Dostarczenie urządzeń wspomagających terapię [10039158];

2. Dostarczenie urządzeń zabezpieczających [10024527];

3. Nauczanie o rehabilitacji [10033017];

4. Ocenianie wzorca mobilności [10030641]; 
5. Ocenianie zdolności do uruchamiania [10030527];

6. Pozycjonowanie pacjenta [10014761];

7. Zapobieganie upadkowi [10040211].

Diagnoza/wynik: Prawidłowy status mięśniowo - szkieletowy [10033807].

Diagnoza pielęgniarska nr 3. Deficyt samoopieki [10022730]. Przedmiot: Zaburzona zdolność uczestniczenia w planowaniu opieki [10035134]; Zdolność wykonywania samoopieki [10023729]. Interwencje:

1. Ocenianie samoopieki [10021844];

2. Ewaluacja planu opieki [10031252];

3. Nauczanie o samoopiece [10045014];

4. Ocenianie samodzielności [10024280];

5. Wzmacnianie samodzielności [10022537];

6. Motywowanie [10012242];

7. Ocenianie radzenia sobie [1002725];

8. Ocenianie możliwości [10026040];

9. Ocenianie potrzeb [10033360];

10. Zarządzanie zaburzonym procesem radzenia sobie [10039284];

11. Ewaluacja psychospołecznej odpowiedzi na plan opieki [10007153].

Diagnoza/wynik: Deficyt samoopieki [10022730].

Diagnoza pielęgniarska nr 4. Nietrzymanie moczu [10025686]. Przedmiot: Trzymanie moczu [10026663]. Nietrzymanie moczu: status trzymania: mimowolne oddawanie moczu, brak świadomej kontroli nad pęcherzem i zwieraczem cewki moczowej. 
Interwencje:

1. Ocenianie trzymania moczu [10030781];

2. Zarządzanie nietrzymaniem moczu [10031879];

3. Zarządzanie cewnikiem urologicznym [10031977];

4. Używanie techniki aseptycznej [10041784];

5. Asystowanie w czynnościach toaletowych [10023531];

6. Utrzymywanie godności i prywatności [10011527];

7. Współdziałanie z lekarzem [10023565];

8. Prewencja infekcji [10036916];

Diagnoza/wynik: Nietrzymanie moczu [10025686], bez infekcji [10028945].

Diagnoza pielęgniarska $\mathrm{nr} \quad 5 . \quad$ Zaburzona aktywność psychomotoryczna [10025087].

Przedmiot: Aktywność psychoruchowa [10016008].

Aktywność psychoruchowa: proces układu nerwowego: koordynacja ruchu, dobrowolnych sposobów poruszania się i mobilizacji aparatu ciała wymagające pewnego stopnia koordynacji nerwowo mięśniowej z wykorzystaniem świadomego działania umysłu.

Interwencje:

1. Promowanie mobilności fizycznej [10037379];

2. Monitorowanie tolerancji aktywności ruchowej [10036622];

3. Zwiększanie tolerancji aktywności [10024884];

4. Promowanie ćwiczeń [10040834];

5. Wzmacnianie techniki wykonywania ćwiczeń mięśni lub stawów [10036512];

6. Nauczanie o sposobie zwiększania tolerancji aktywności ruchowej [10024660];

Diagnoza/wynik: Dobra funkcja motoryczna [10043026]. 
Diagnoza pielęgniarska nr 6. Ryzyko odleżyny [10027337].

Przedmiot: Odleżyna [10015612].

Odleżyna: wrzód: uszkodzenie, stan zapalny oraz bolesność skóry lub tkanki podskórnej, wywołana uciskiem na tkanki i nieadekwatnym ukrwieniem.

Interwencje:

1. Ocenianie ryzyka odleżyny [10030710];

2. Ocenianie integralności skóry [10033922];

3. Pozycjonowanie pacjenta [10014761];

4. Używanie wsparcia do pozycjonowania [10035467];

5. Nauczanie o higienie [10044549];

6. Asystowanie w higienie [10030821];

7. Pielęgnacja skóry [10032757];

8. Prewencja odleżyny [10040224];

Diagnoza/wynik: Bez odleżyny [10029065].

Diagnoza pielęgniarska nr 7. Niewyraźna mowa [10018304]. Przedmiot: Dysfazja [10006457].

Niewyraźna mowa: dysfazja: niewyraźne lub niepełne wypowiadanie słów, zlewanie się słów lub ich częściowe pomijanie; związane z osłabieniem mięśni odpowiedzialnych za artykulację, uszkodzeniami układu nerwowego, zażywaniem specyfików lub niedbałą wymową. Interwencje:

1. Identyfikowanie przeszkody w komunikacji [10009683];

2. Ocenianie radzenia sobie rodziny [10026600];

3. Ocenianie własnego wizerunku [10027080];

4. Ocenianie zdolności do komunikacji przez mówienie [10030515];

5. Nauczanie pacjenta [10033086];

6. Nauczanie opiekuna [10033086];

Diagnoza/wynik: Gotowość do prawidłowej komunikacji [10001430]. 
Diagnoza pielęgniarska nr 8. Niepokój [1000477].

Przedmiot: Niepokój [10002429].

Niepokój: emocja negatywna: poczucie zagrożenia, niebezpieczeństwa lub dystresu.

Interwencje:

1. Ocenianie statusu psychologicznego [10030734];

2. Zarządzanie negatywnymi emocjami [10031851];

3. Zarządzanie niepokojem [10031711];

4. Wprowadzanie terapii odwracania uwagi [10030348];

5. Nawiązywanie kontaktu [10016678];

6. Ocenianie strachu [10024267];

7. Ocenianie postawy wobec reżimu terapii [10024205];

Diagnoza/wynik: Zmniejszający się niepokój [10027858].

\section{Wnioski}

Z zastosowaniem klasyfikacji ICNP® możliwe jest ukazanie prawdziwego stanu zdrowia pacjenta po przebytym udarze niedokrwiennym mózgu oraz prawidłowe zaplanowanie działań pielęgniarskich, opierając się o jednolitą terminologię zawodową.

\section{Bibliografia/ Bibliography}

1. Jaracz K., Kozubski W. Pielęgniarstwo neurologiczne. Podręcznik dla studiów medycznych. Wydawnictwo Lekarskie PZWL, Warszawa 2008.

2. Pączek L., Mucha K., Foroncewicz B. Choroby wewnętrzne. Podręcznik dla studentów pielęgniarstwa i położnictwa. Wydawnictwo Lekarskie PZWL, Warszawa 2004.

3. Wieczorkowska-Tobis K., Talarska D. Geriatria i pielęgniarstwo geriatryczne. Wydawnictwo Lekarskie PZWL, Warszawa 2008.

4. Domagała W., Chosia M., Urasińska E. Podstawy patologii. Wydawnictwo 
Lekarskie PZWL, Warszawa 2010.

5. Kózka M., Rumian B., Maślanka M. Pielęgniarstwo ratunkowe. Wydawnictwo Lekarskie PZWL, Warszawa 2013.

6. https://www.icn.ch/what-we-do/projects/ehealth/icnp-browser [dostęp $\mathrm{z}$ dnia 10.04.2020r.]. 